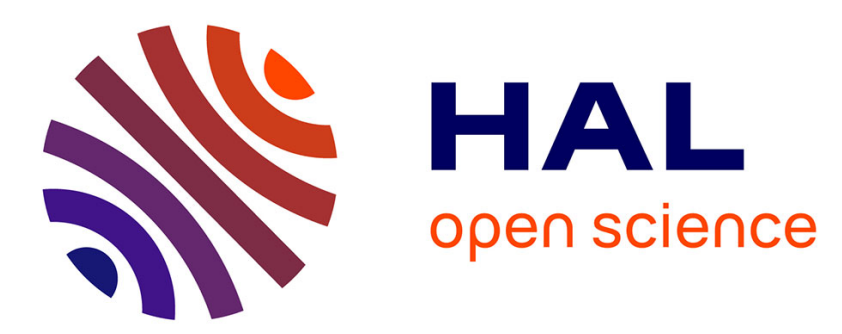

\title{
Effects of the Little Ice Age on avalanche boulder tongues in the French Alps(Massif des Ecrins)
}

\author{
Vincent Jomelli, Pierre Pech
}

\section{To cite this version:}

Vincent Jomelli, Pierre Pech. Effects of the Little Ice Age on avalanche boulder tongues in the French Alps(Massif des Ecrins). Earth Surface Processes and Landforms, 2004, 29 (5), pp.553-564. 10.1002/esp.1050 . hal-03037002

\section{HAL Id: hal-03037002 https://hal.science/hal-03037002}

Submitted on 4 Dec 2020

HAL is a multi-disciplinary open access archive for the deposit and dissemination of scientific research documents, whether they are published or not. The documents may come from teaching and research institutions in France or abroad, or from public or private research centers.
L'archive ouverte pluridisciplinaire HAL, est destinée au dépôt et à la diffusion de documents scientifiques de niveau recherche, publiés ou non, émanant des établissements d'enseignement et de recherche français ou étrangers, des laboratoires publics ou privés. 


\title{
EFFECTS OF THE LITTLE ICE AGE ON AVALANCHE BOULDER TONGUES IN THE FRENCH ALPS (MASSIF DES ECRINS)
}

\author{
VINCENT JOMELLI ${ }^{1 *}$ AND PIERRE PECH ${ }^{2}$ \\ ${ }^{1}$ Laboratoire de Géographie Physique, CNRS UMR 8591, 1 place A Briand, 92195 Meudon Bellevue, France \\ ${ }^{2}$ Université Paris 1 Panthéon Sorbonne, 191 rue St Jacques, 75005 Paris, France
}

Received 30 November 2001; Revised 18 July 2003; Accepted 29 July 2003

\begin{abstract}
Lichens of the subspecies Rhizocarpon geographicum s.l were measured on 25 avalanche boulder tongues in the Massif des Ecrins to elucidate the Little Ice Age history of avalanche activity. Results show: (1) an increase of lichen size from the median to the distal zone of deposits, and a decrease from the edges to the centre; (2) three types of lichen settlement. From the uppermost to the median zone, lichens are absent, because avalanche activity is very active. Down-slope, lichens occur in two different zones: the median zone is colonized by $5-20 \mathrm{~mm}$ size lichens on sides of blocks protected from the abrasional action of avalanches, while in the distal zone lichen diameters are largest $(>30 \mathrm{~mm})$ and occur on all sides of the blocks.

The spatial distribution of the lichens and their size according to elevation make it possible to distinguish different phases during which avalanche activity has increased. At high elevation, the avalanche activity was at a maximum before AD 1650 and between AD 1730 and 1830. During these two periods avalanches had sufficient magnitude to reach the basal zone of the deposits. At low elevation since AD 1650 the magnitude and frequency of avalanches have declined. Copyright () 2004 John Wiley \& Sons, Ltd.
\end{abstract}

KEY WORDS: avalanche boulder tongue; lichenometry; Little Ice Age; French Alps

\section{INTRODUCTION}

Increased attention has been paid in the last 20 years to the impacts of the Little Ice Age on different periglacial environments. A very large range of processes and slope deposits have been studied. Previous works on this topic were mostly on debris flows (Rapp and Nyberg, 1981; Innes, 1985b; Nyberg, 1985; Van Steijn, 1996), rock glaciers (Evin and de Beaulieu, 1985; Haeberli, 1985; Evin, 1987; Hamilton and Whalley, 1995; Humlum, 1996, 1999; Haeberli and Beniston, 1998; Francou et al., 1999), and rock avalanches (Grove, 1972, 1988; Porter and Orombelli, 1980). Lichenometric measurements (Gray, 1973; Innes, 1985b; Luckman and Fisk, 1995; McCarroll et al., 1998), dendrochronological observations (Hétu, 1990; Lafortune et al., 1997) or sedimentation rates (Kotarba et al., 1987; André, 1997; Blikra and Selvik, 1998) show that climatic changes, which occurred since the Little Ice Age, induce diachronous variations in slope processes. These variations are highlighted by: (i) the frequency and intensity of processes; and (ii) an initiation or elimination of previously inactive or active processes (Kotarba and Stromquist, 1984; Rapp and Nyberg, 1988; Nyberg and Lindh, 1990; Eybergen and Inmeson, 1989; Schlyster et al., 1993; André, 1995).

However, little attention has been paid to the pattern of snow avalanche processes during and after the Little Ice Age. Until now most studies have been performed in northern Europe (Grove, 1972; Nyberg, 1985; McCarroll, 1993; Mathews and McCarroll, 1994; Bull et al., 1995; Blikra and Nemec, 1993, 1998), a region with a special morphoclimatic context. In alpine environments, such observations are still lacking, especially for the French Alps (V. Jomelli, unpublished work, 2000). The aim of this paper is to provide information on the effects of the Little Ice Age on avalanche boulder tongues in part of the French Alps, using an improved lichenometric method performed on a large sample of deposits.

\footnotetext{
* Correspondence to: V. Jomelli, Laboratoire de Géographie Physique, CNRS UMR 8591, 1 place A Briand, 92195 Meudon Bellevue, France. E-mail: jomelli@cnrs-bellevue.fr
} 


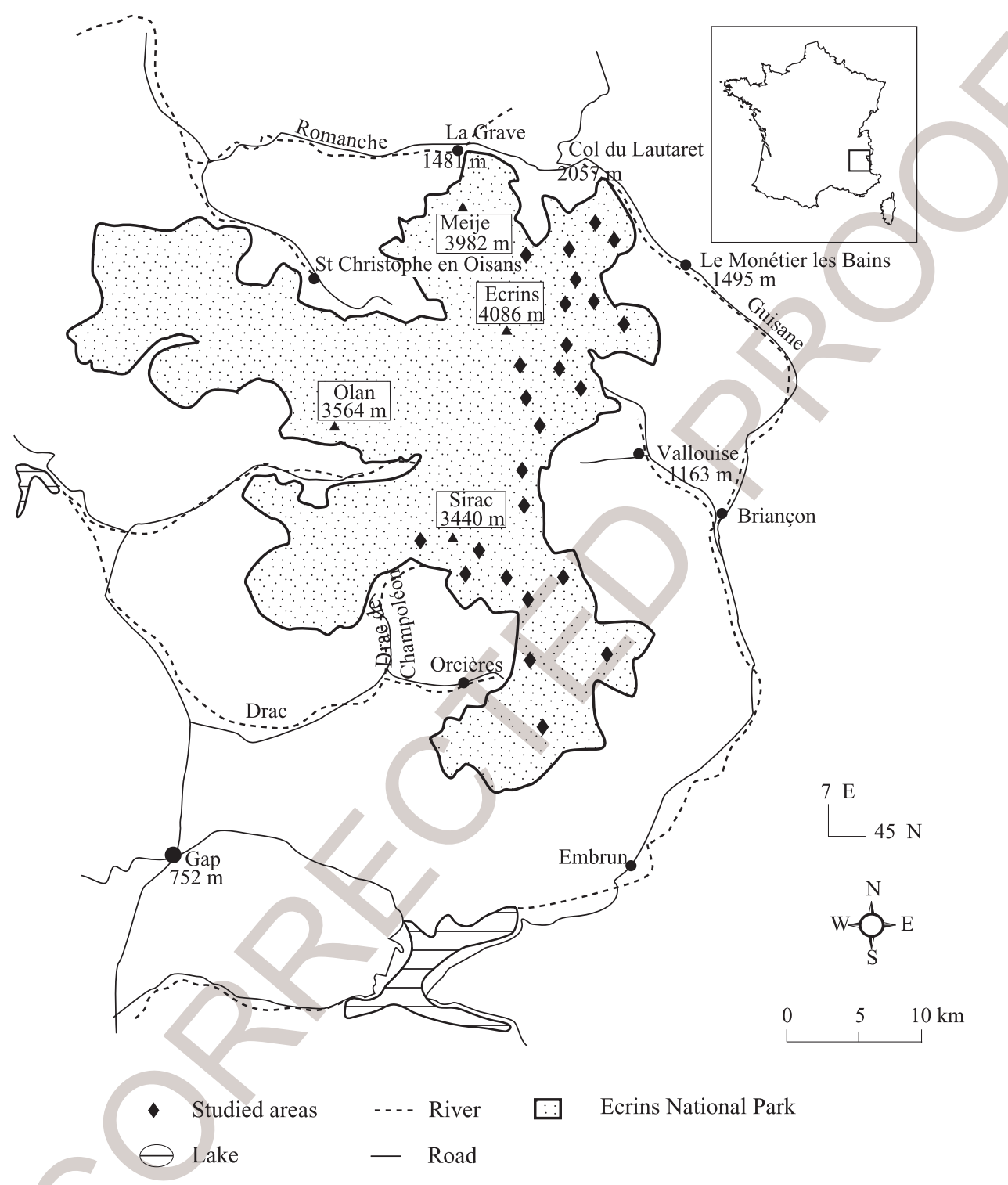

Figure 1. Location map of the Massif des Ecrins including the study sites

\section{STUDY SITES}

The field area is the eastern part of the Massif des Ecrins (French Alps, 450 $00^{\prime} \mathrm{S}, 6^{\circ} 30^{\prime} \mathrm{E}$ ) (Figure 1). The studied avalanche boulder tongues are situated between 1800 and $2450 \mathrm{~m}$ a.s.l., an elevation which is close to the annual $0{ }^{\circ} \mathrm{C}$ isotherm. At this altitude, 60 per cent of the precipitation is snow. Snow covers the ground from October to June, with a maximum thickness of $3 \mathrm{~m}$ (Francou, 1983, 1988). The boulder tongues used in the present study are the result of sedimentation from successive wet snow avalanches (Jomelli and Bertran, 2001) (Figure 2). Generally they are located below north-facing cliffs, of varying angles, where debris and snow tend to accumulate on the low-angle cliffs.

The occurrence of dirty avalanches is highest in May and June. The debris transported by snow avalanches consists of blocks of granite and gneiss ranging between 10 and $50 \mathrm{~cm}$ (a-axis), and matrix including sands and a smaller proportion of silt. Accretion rates, evaluated for at least 3 years, are between $0 \cdot 02$ and $0 \cdot 35 \mathrm{~mm} \mathrm{a}^{-1}$ 


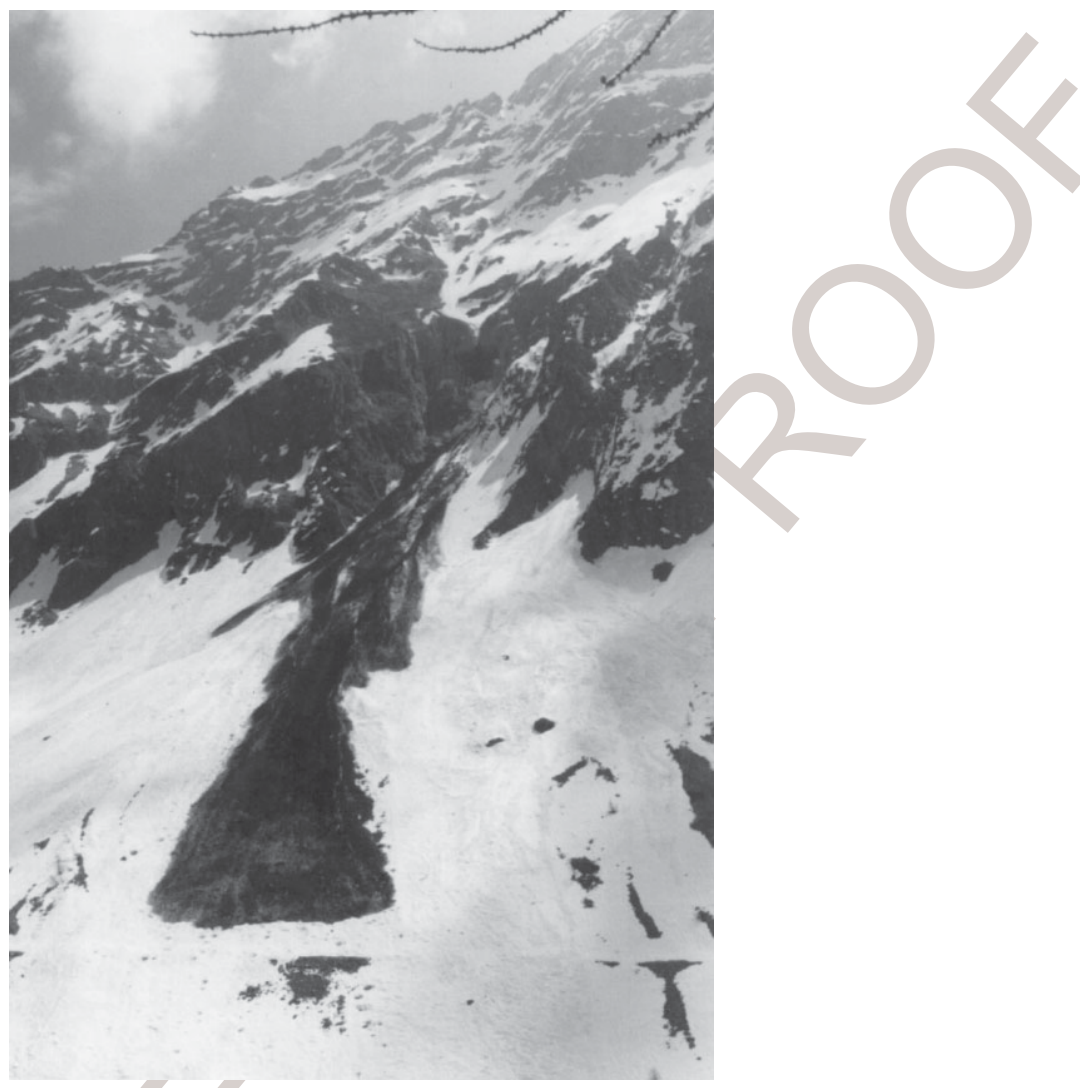

Figure 2. Wet snow avalanche of $450 \mathrm{~m}$ length in the Champoleon valley in spring 1998

(Jomelli, 1997), with values higher than $2 \mathrm{~mm} \mathrm{a}^{-1}$ on the very active north-facing cliffs (Francou and Reynaud, 1992).

\section{METHODS}

Measurements of Rhizocarpon sp. (ex Rhizocarpon geographicum) lichens were performed during two field campaigns on 25 deposits for which geometrical and sedimentological characteristics have been studied previously (Jomelli, 1997, 1999). The value of the minimum diameter of the largest lichen was collected with a flexible, transparent plastic ruler on blocks in rectangular sample areas of $5 \times 20 \mathrm{~m}$ according to methods developed by Innes (1985a, 1986b) and McCarroll (1993, 1994). These surface areas have been distributed in a draught-board pattern on deposits. The location of lichens on boulders, in relation to the supposed trajectories of avalanches, was also noted. Between 15 and 70 measurements (one measurement on each block) were made within each sample area. This minimum value of 15 measurements in each sample area was used to define the 'green zone' (Innes, 1985a). Sample surfaces with less than 15 blocks colonized were considered as free of lichens. The minimum diameter counted was $5 \mathrm{~mm}$ with an accuracy of $1 \mathrm{~mm}$. Anomalous lichen shapes were rejected to reduce the risk of coalescence. Measurements were performed on the 'upper surface' and 'sides' of boulders with an a-axis between $15 \mathrm{~cm}$ and $100 \mathrm{~cm}$.

To compare the lichen pattern between deposits, the length of the deposits was measured over a constant segment of $10 \mathrm{~m}$. To facilitate comparison, the distances from the apex of the deposit are divided by the total length of the deposit (fractionated distance from the apex) and converted to percentages (Francou, 1988; Jomelli and Francou, 2000). Finally, to date this avalanche activity we used a lichenometric growth curve (Figure 3) constituted for the massif des Ecrins (Pech et al., 2002). 


\section{RESULTS OF THE LICHENOMETRIC APPROACH}

On avalanche boulder tongues lichen settlement changes spatially, with clear boundaries as shown on the four representative examples on Figure 4. In proximal and sometimes in median zones thalli are scarce $(<15$ in each sample area) or absent. This surface, named 'type 1', represents between 40 and 70 per cent of the total surface (Table I). Down-slope, another type of surface is observed on which lichens occur on sides of blocks protected from the abrasional action of avalanches. This surface, named 'type 2', represents between 12 and 26 per cent of the total surface. In the distal zone, we observed a 'type 3' surface on which lichens occur on all faces of blocks, especially those potentially exposed to snow avalanche impacts. The dimensions of this surface are variable and sometimes (three cases out of 20) can be limited to edges along lateral axes (Figure 4a). Locally, we found small surfaces without lichen within zones of types 2 and 3 (arrow in Figure 4a). Along the median

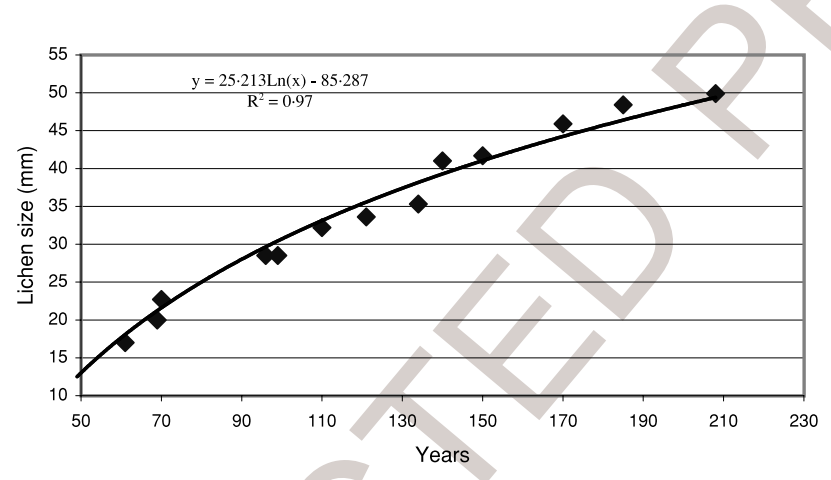

Figure 3. Rhizocarpon growth curve in the eastern side of the Massif des Ecrins

Table I. Elevation and lichenometric measurements on avalanche boulder tongues

\begin{tabular}{rcccccc}
\hline Deposit & $\begin{array}{c}\text { Type } 1 \\
(\%)\end{array}$ & $\begin{array}{c}\text { Type 2 } \\
(\%)\end{array}$ & $\begin{array}{c}\text { Type } 3 \\
(\%)\end{array}$ & $\begin{array}{c}\text { Mean size of the 5 } \\
\text { largest lichens }\end{array}$ & $\begin{array}{c}\text { Elevation } \\
(\mathrm{m})\end{array}$ & $\begin{array}{c}\text { Number of } \\
\text { measurements }\end{array}$ \\
\hline 1 & 50 & 19 & 31 & $5 \cdot 7$ & 1810 & 599 \\
2 & 56 & 21 & 23 & $5 \cdot 4$ & 1860 & 677 \\
3 & 35 & 28 & 37 & $5 \cdot 9$ & 1920 & 828 \\
4 & 44 & 24 & 32 & $5 \cdot 8$ & 1930 & 749 \\
5 & 57 & 18 & 25 & $5 \cdot 8$ & 2000 & 734 \\
6 & 38 & 23 & 39 & $5 \cdot 6$ & 2010 & 804 \\
7 & 51 & 20 & 29 & $5 \cdot 9$ & 2040 & 634 \\
8 & 48 & 13 & 39 & $5 \cdot 4$ & 2080 & 639 \\
9 & 45 & 10 & 45 & $5 \cdot 7$ & 2130 & 802 \\
10 & 66 & 12 & 18 & $4 \cdot 4$ & 2140 & 678 \\
11 & 65 & 16 & 19 & $4 \cdot 3$ & 2150 & 649 \\
12 & 61 & 22 & 17 & $4 \cdot 2$ & 2180 & 695 \\
13 & 50 & 21 & 29 & $4 \cdot 4$ & 2200 & 728 \\
14 & 52 & 26 & 22 & $4 \cdot 3$ & 2240 & 705 \\
15 & 70 & 16 & 14 & $5 \cdot 4$ & 2250 & 655 \\
16 & 67 & 18 & 15 & $3 \cdot 8$ & 2260 & 701 \\
17 & 66 & 14 & 20 & $5 \cdot 8$ & 2280 & 916 \\
18 & 65 & 17 & 18 & $4 \cdot 5$ & 2300 & 812 \\
19 & 62 & 16 & 22 & $5 \cdot 9$ & 2300 & 723 \\
20 & 54 & 31 & 15 & $4 \cdot 3$ & 2330 & 863 \\
21 & 57 & 26 & 17 & $5 \cdot 8$ & 2420 & 891 \\
22 & 59 & 14 & 27 & $4 \cdot 3$ & 2420 & 802 \\
23 & 54 & 30 & 16 & $4 \cdot 4$ & 2450 & 784 \\
24 & 53 & 25 & 22 & $4 \cdot 4$ & 2460 & 630 \\
25 & 55 & 19 & 26 & $4 \cdot 3$ & 2460 & 690 \\
\hline & & & & & & \\
\hline
\end{tabular}



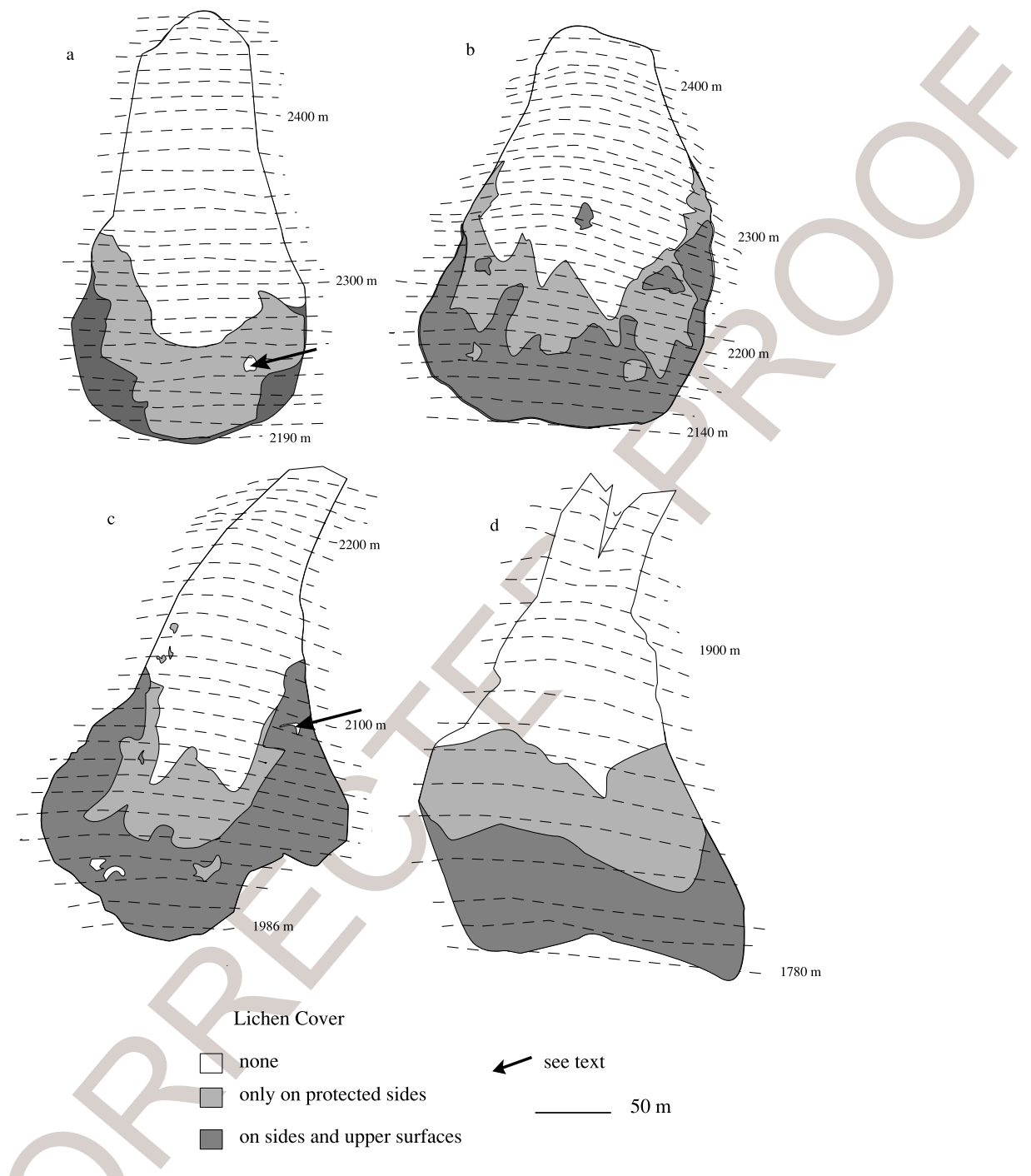

Figure 4. Lichen colonization types on four examples of avalanche boulder tongues

axis, type 1 covers about 7/10 of the distance down-slope from the apex while type 3 is found only from 9/10 to the lowermost end of the profiles. Along the sides, however, type 1 is rarely found below 5/10 of the downslope distance and type 3 occurs below 8/10. In other words, along the sides of the deposits types 2 and 3 are present higher up-slope than in their central parts.

The extent of the different zones changes with elevation. But, with these data, there seems no simple relation between those two parameters. Nevertheless it is noted that the extent of zone 1 on avalanche boulder tongues is generally smaller at low elevation $(<2150 \mathrm{~m}$, corresponding to the altitudinal average of the avalanche boulder tongues selected in this study) compared to higher elevation. In other words, at low elevation the lichens appear up-slope on the profile of the deposits, from 4/10 to 5/10. Finally, for deposits located at equal elevation, the extent of the different zones changes across the slope direction (Figure 4).

Lichen size-frequency distributions were performed for each avalanche boulder tongue (Figure 5a-d). Results show variable characteristics from one to another. Form is rarely symmetric, as confirmed by skewness values between $-0 \cdot 3$ and $0 \cdot 2$; only Figure $5 \mathrm{~b}$ and c show a weak skewness $(0 \cdot 07,0 \cdot 09$, respectively). Largest diameter values show large variations according to elevation. Below $2150 \mathrm{~m}$ the maximum values of thalli are close to $5.8 \mathrm{~cm}$. Largest diameter values remain relatively constant from one deposit to another whether or not located 

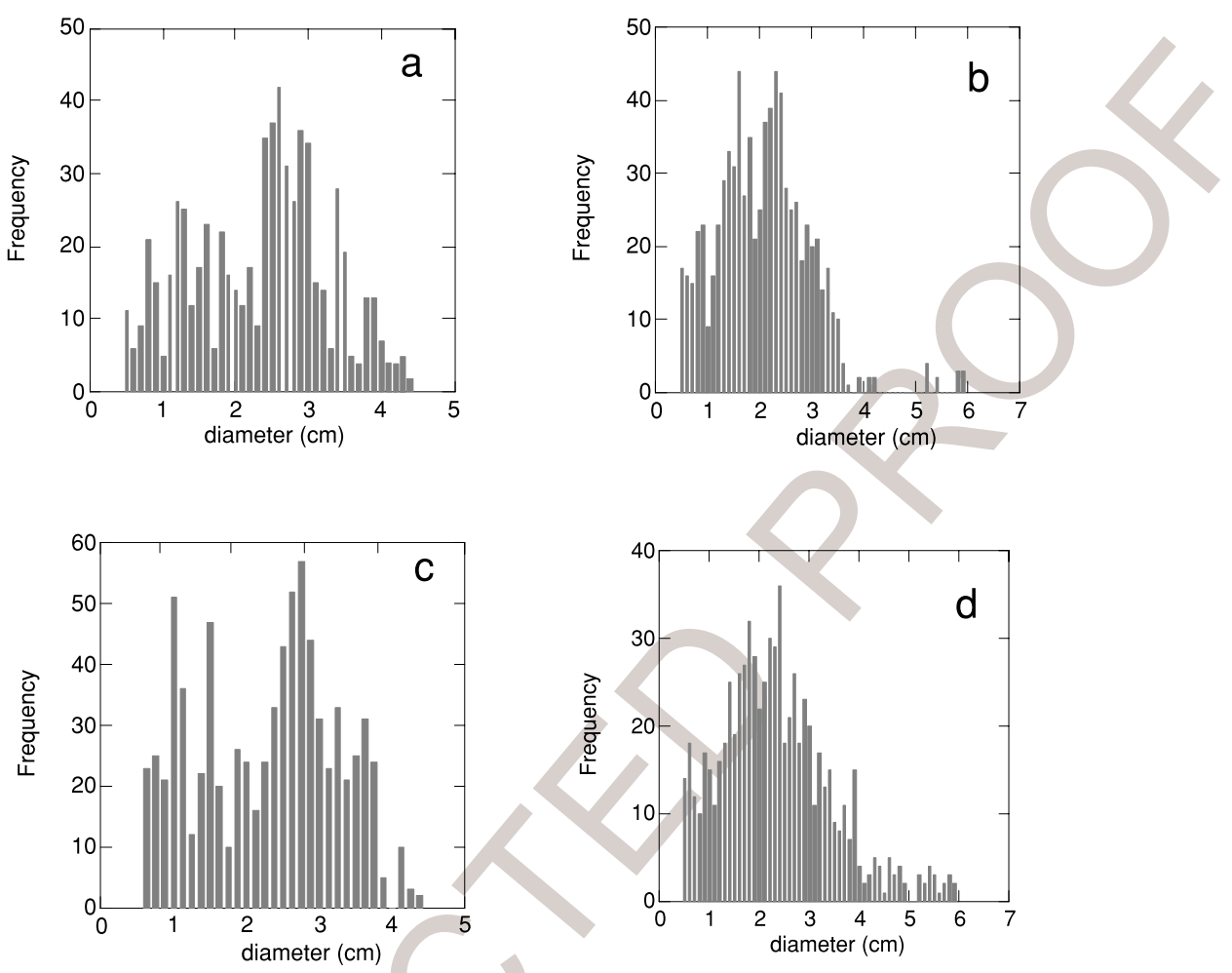

Figure 5. Lichen size-frequency distributions for the four examples of avalanche boulder tongues

in the same valley. Modal values are between 2.3 and $2.5 \mathrm{~cm}$. Above $2150 \mathrm{~m}$ the largest thalli diameters show a complex distribution according to avalanche boulder tongues. Maximum values are lower by at least $1.3 \mathrm{~cm}$ than those measured at low elevation. Modal values are most often between 21 and $31 \mathrm{~mm}$. In detail, the distributions show several modes which are frequently between 20 and $27-28 \mathrm{~mm}$ (Figure 5b). From these first measurements, some larger lichen have been observed located mainly on blocks in the distal zone. These very large lichens are developed in most cases only on the sides of blocks protected from the abrasional action of avalanches.

Figure $6 \mathrm{a}-\mathrm{d}$ displays the mean size of the five largest diameters on each sample surface along median and lateral axes. Results show a clear down-slope increase of the median size of the five largest lichens and a decrease from the edges to the centre. This pattern is relatively consistent from one deposit to another but differs between median and lateral axes on deposits. Along the median axis, the increase is not linear (Figure 7). It is roughly at $7 / 10$ to $8 / 10$ of the profile then more regular down-slope. Below $8 / 10$, the increase of lichen size is stronger when type 3 exists (Figure 6b, c). Along the edges of the deposits, lichen sizes are larger (usually by more than $0.5 \mathrm{~cm}$ ) compared to that on the central parts at the same relative distance from the apex. In the distal zone of high elevation deposits, the maximum size is generally around $3.5-4 \mathrm{~cm}$; but in rare cases, values can exceed $5.5 \mathrm{~cm}$. However, the very small number of blocks (specified by the number in parentheses on Figure 6b), on which we observed these very large lichens, does not permit any zones to be distinguished. On the contrary, at low altitude the lichen size frequently exceeds $4.5 \mathrm{~cm}$ in the distal zone.

\section{DISCUSSION}

The lichenometry can be used to analyse the spatial frequency/run-out variation of avalanches and to date these variations. The down-slope change of lichen-colonization types, usually used in relative dating (Innes, 1986a), underlines spatial aspects of snow avalanche sedimentation and allows an identification of variations in the frequency and run-out distance of snow avalanches. This variation is partly due to the magnitude of geomorphic 

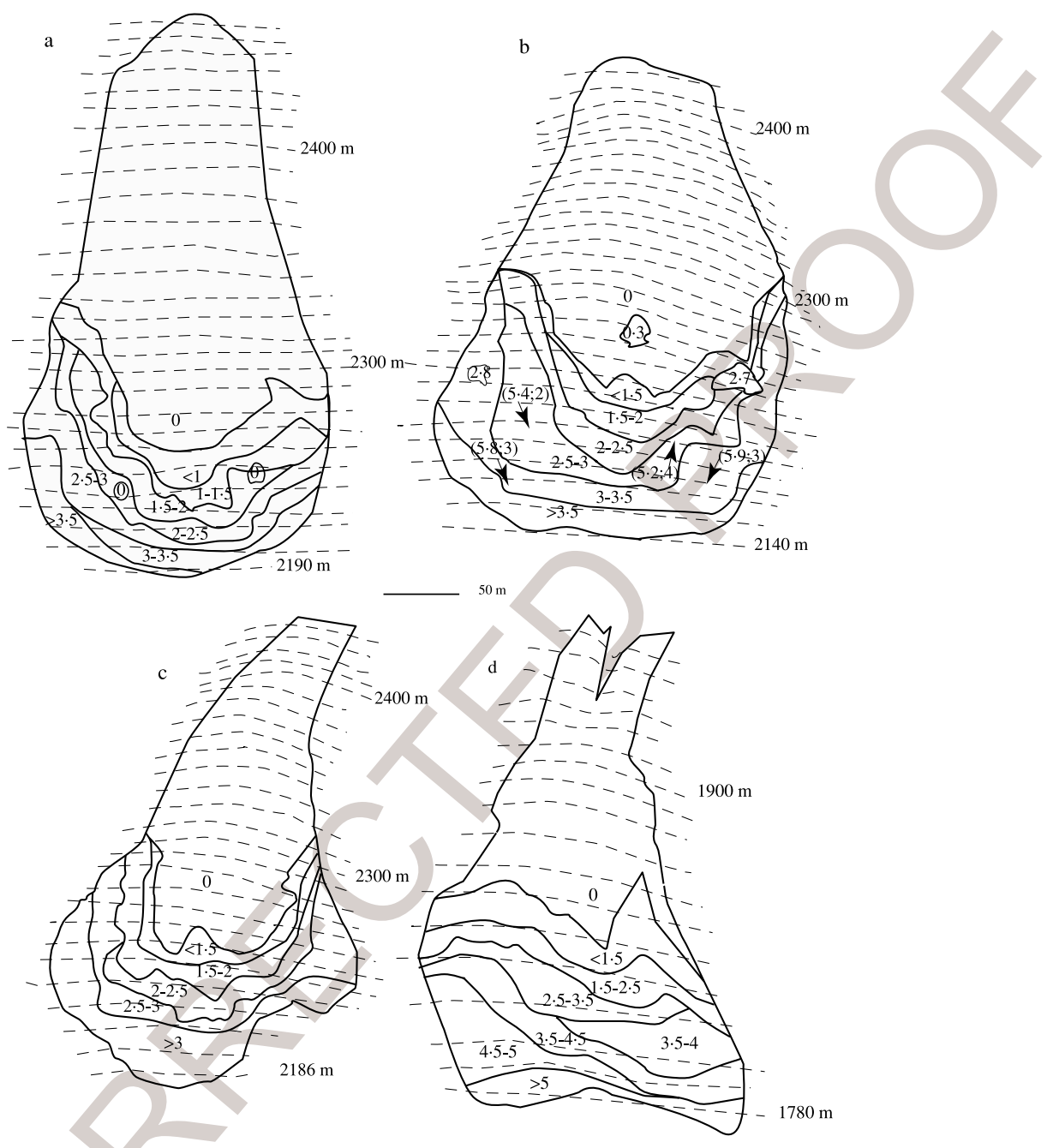
in brackets: size $(\mathrm{cm})$ and number of cases respectively

3.5-4 Lichen size $(\mathrm{cm})$ according to the five largest diameters

Figure 6. Distribution of the five largest lichens on each of $n$ boulders on the four examples of avalanche boulder tongues. In (b) is an example of a special deposit on which very large lichens have been observed; outlines do not take into account these special extreme values

activity controlled by the snow-avalanche processes (erosion, transport and sedimentation). Generally, this geomorphic action decreases irregularly down-slope (Figures 4-6), as has been observed in previous studies (Luckman, 1988).

From the apex to the upper 7/10, geomorphic activity is high and prevents lichen colonization of the deposit. We deduce that avalanche frequency is high for run-out distances less than 7/10 of the slope. Field observations between 1993 and 2001 indicate that these avalanches have a recurrence time of between 1 and 5 years. However, snow avalanches with larger run-out distance will also occur but at a lower frequency. Parts of the lichen distribution in Figure 5 can thus be attributed to such time-frequency systems. Consequently, the following hypothesis can be formulated: the avalanches can still reach this median zone but they are not very frequent or/and have a lower abrasive power; so lichens can grow on the protected sides of blocks. This hypothesis 


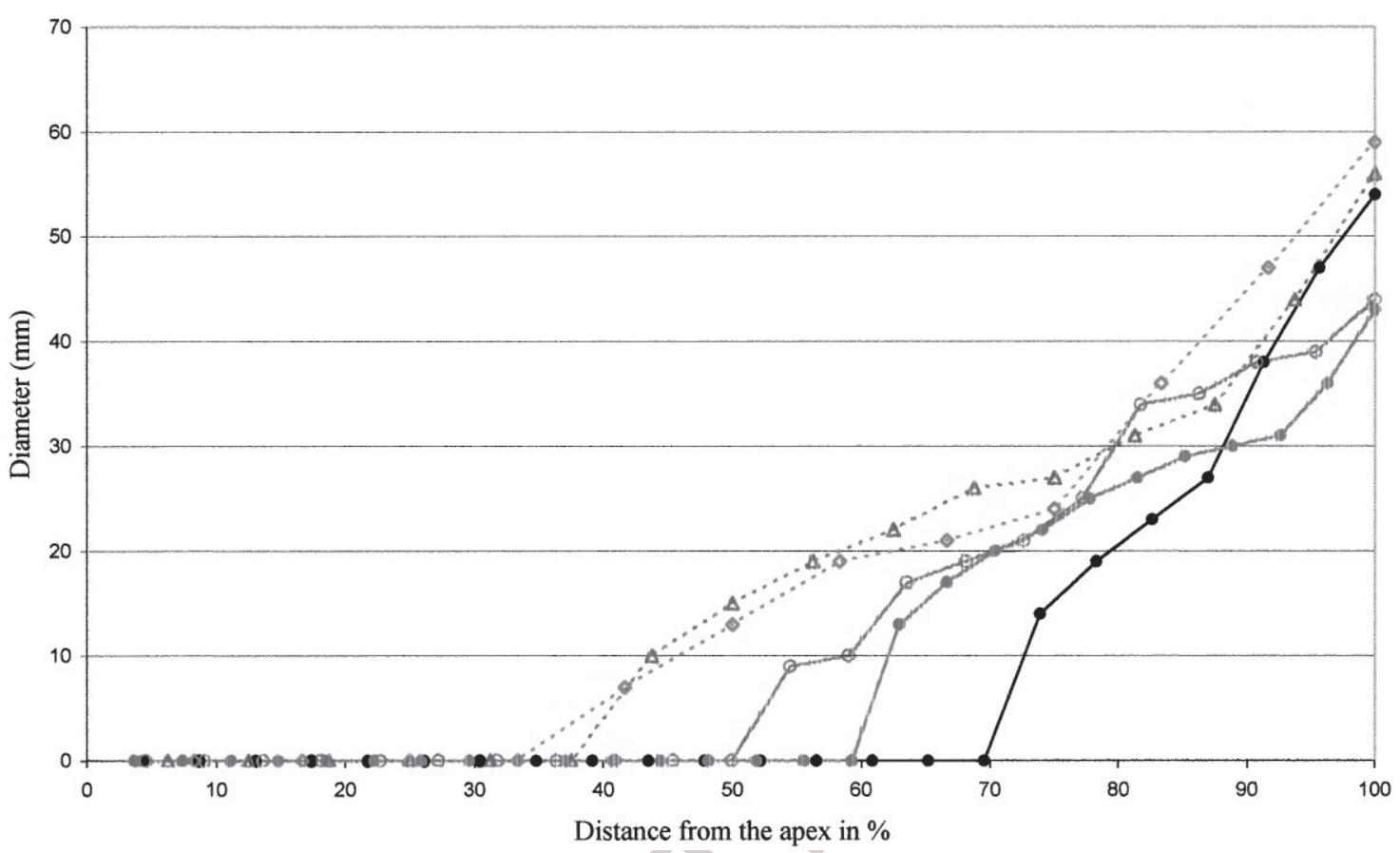

Figure 7. Down-slope evolution along the median axis of the deposit of the mean of the five largest diameters on five snow avalanche boulder tongues: dotted lines indicate low elevation boulder tongue; solid lines indicate high elevation boulder tongue

considers that the median zone is still active. Down-slope, the frequency of avalanches reaching 9/10 of the profile is very low, so lichens are older than on the other parts of the deposit. Locally, we observed small surfaces where lichens are absent within zones of types 2 and 3. This demonstrates the spatial heterogeneity of the avalanches' geomorphic action. Nevertheless, this action is stronger on the central axis.

Lichenometry also allows us to show a diachronicity in sedimentation on avalanche boulder tongues during the Little Ice Age (LIA). According to the lichen patterns, an irregular decrease of avalanche run-out distances has occurred for these last centuries (Figures 4-6). However, a distinction must be made according to the elevation.

At high elevation, we have observed large lichens on four avalanche boulder tongues. However, their position on the blocks and their size in comparison to those observed on the other blocks suggest that they are the remnants of an old phase of colonization. The high erosive potential of avalanches would be responsible for their disappearance on the other fans. If one takes into consideration these largest lichens, it seems that the activity of the avalanches was restricted to the distal zone between 1650 and 1700 (if an extrapolation of the lichen growth curve is made). Before the middle of the seventeenth century, avalanches therefore, had a magnitude sufficient to reach this basal zone and to deposit large blocks. Their frequency was sufficiently high to prevent lichens from colonizing the deposits. This high period of avalanche activity could be viewed as a first maximum during the LIA. However, the exact age of the blocks in the distal zone is difficult to determine because they could also be considerably older than the beginning of the LIA. It is possible that previously deposited boulders were covered by enhanced accumulation during this first LIA maximum. Between 1650 and 1730 avalanche activity decreased, allowing free development of lichens on the surface of snow avalanche fans. Between 1730 and 1830, the activity of the avalanches seems to have increased. Such an evolution could be responsible for the disappearance of most of the lichens which developed during the former period. Only occasional lichens located on protected sides of blocks survived this erosive activity. From about 1830 to 1850 , according to the mean of the five largest lichens (Table I), the frequency of the avalanches reaching the distal zone was extremely low. Alternatively, it may reflect a decrease in the quantity of debris transported by avalanches, reducing their erosive power. However, various results in the literature suggest an increase in frost shattering during the LIA. 
Moreover, Jomelli (1997), from observations carried out on wet snow avalanche deposits, did not observe any relation between the quantity of debris and the length of the wet snow avalanche deposits. On the contrary, a positive linear relationship is observed between the maximum size of rock debris and the volume of wet snow deposits (Jomelli and Bertran, 2001). So, this decrease in run-out distance allowed lichens to colonize the basal zone. Consequently, at this elevation, a second maximum in avalanche activity occurred at the beginning of nineteenth century.

Between 1830 and present, two contrasting periods can be distinguished: Because lichen size decreases from the base to the median part of all deposits, the magnitude of avalanches has decreased to 30 per cent between 1830 and 1950. This decrease seems to be due to a lower frequency, and explains the pattern of lichen distribution described earlier. From 1950, magnitude is low but frequency remains high in the upper part of the deposits.

At low elevation, the variation of the avalanche activity during the LIA is appreciably different. The lack of a clear hiatus in the distribution of the lichens suggests that there was a maximum in avalanche activity around AD 1600-1650 (according to the lichen growth curve extrapolation). Since around 1700, colonization by lichens in the distal zone of avalanche boulder tongues is observed, which is due to a decrease in activity of this process. The phase observed around AD 1830, during which maximum run-out distances at high altitude occurred, also exists at low altitude, but the activity was less intense.

The run-out distance variation of wet snow avalanches in a couloir since AD 1600-1650 could depend on a decrease in the amount of snow mobilized, if we suppose that the coefficients of friction were constant over the whole period (Voellmy, 1955). Can we deduce from these observations that precipitation was higher than at present? The answer is complex because until now most work shows no direct relation between the frequency or the intensity of an avalanche and precipitation (Föhn, 1992; Schneebeli et al., 1997). Nevertheless, this assumption of a greater quantity of snow mobilized by avalanches during the LIA can be supported by the fact that the two periods, AD 1600-1650 and 1830, during which the run-out distances were maximum at high elevation sites, have corresponded overall to the periods of maximum glacial advances for these last 500 years (Le Roy Ladurie, 1983; Reynaud, 2001). The first major glacial advance of the LIA ranges between 1600 and 1650 depending on the glaciers, and the second between 1800 and 1850 . Since 1850 most French Alpine glaciers have decreased. Moreover, the mass balance of these glaciers is directly correlated with summer temperature and spring precipitation (Vincent and Vallon, 1997; Vincent, 2001, 2002). At a larger scale, this relation is confirmed by historical analyses which show a decrease of the Buêch floods at the end of the Little Ice Age (Gautier, 1992), reflecting a decrease of either snow precipitation or snow mantle duration in this part of France.

In other mountainous areas, in particular in northern Europe, the phase of maximum avalanche activity has been frequently recorded around 1850 (Grove, 1988; Mathews and McCarroll, 1994; Bull et al., 1995; McCarroll et al., 1995). More rarely this occurred around AD 1650 (Grove, 1972; Grove and Battagel, 1983) or at the beginning of the twentieth century (Blikra and Selvik, 1998). The different climatic conditions (Jacobeit et al., 2001) which explain the opposition currently observed between the dynamics of the Scandinavian glaciers and that of the French glaciers (Six et al., 2001) could also explain this temporal shift in avalanche activity.

Considering the specific context of this study (avalanches boulder tongues, high elevation, Little Ice Age period), it could be answered that the lichenometric variations simply underline the presence of firns on the avalanche boulder tongues, which would have been responsible for a decrease in the growth rate in the distal zone and the deterioration of the lichens in the proximal and median zones of the deposits? Without excluding a punctually influence, two arguments make it possible to refute this assumption for all of the sites:

Weather data gathered since the 1980s in one of the selected sectors (Francou, 1988; Bocquet, 2001) added with field observations carried out annually since 1993 show that up to $2500 \mathrm{~m}$ in altitude, the snow does not remain on the ground between the middle of June and the beginning of October on the northern slopes. However these three months without snow cover are sufficient for the normal development of the lichens (Benedict, 1990, 1991). If the comparison between climatic conditions of the 1980s and those of the LIA is debatable, it is difficult to understand why no lichen can grow in the proximal and median zones of the deposits since the 1950s without taking into account the action of the avalanches.

Moreover, if climatic conditions during LIA would not permit the development of lichens or their maintenance, it is difficult to explain lichens larger than $5 \mathrm{~cm}$ on rock glaciers observed in these same valleys above $2400 \mathrm{~m}$ in altitude. 
Some local factors may influence the general tendency explained above. We consider that differences between avalanche boulder tongues on figures $6 \mathrm{a}, \mathrm{b}$ and $\mathrm{c}$ could be explained by morphological factors. As altitude and aspect are similar for these sites, these factors are not pertinent, as has been observed elsewhere (Benedict, 1991). Differences of colonisation and of lichen size observed between deposits could be linked to the slope angle and length of the rock wall above each deposit. It was shown that these variables control snow avalanche run-out distances (Voellmy, 1955; Norem et al., 1989; Jomelli, 1997). These variables could explain the fact that for a certain relative position on a profile, the size of the five largest lichens is not equal between two deposits situated in the same valley.

Usually the Little Ice Age impact on periglacial slope deposits can be summarized as either a frequency/ intensity variation of given processes, or as the activation of previously inactive processes (and vice versa). More rarely, morphological and sedimentological modifications on deposits are documented (Mathews and McCarroll, 1994; Humlum, 1996, 1999). In this paper analysis of lichemonetric data confirms an earlier hypothesis which links some special morphological and sedimentological characteristics of avalanche boulder tongues (a break point with relatively constant coordinates on the longitudinal profile and an increase of block size in the distal zone) (Jomelli, 1999) to a superposition of two deposits linked to dynamic variations since the Little Ice Age. A first generation of wet snow avalanches involving a large amount of snow and coarse debris has developed a long and smooth concavity. Later, less powerful snow avalanches have constructed a newer deposit closer to the proximal zone, the contact between the two deposits being marked by a geometric discontinuity. This change of wet snow avalanche activity may reflect the end of the Little Ice Age, the less powerful snow avalanches belonging to attenuated snow conditions after the Little Ice Age.

\section{CONCLUSION}

Analysis of colonization patterns and thallus diameter variation on 25 avalanche boulder tongues in the French Alps illustrates variations in the evidence a frequency/run-out of wet snow avalanches since the Little Ice Age. According to the lichenometric measurements at high elevation, the avalanche activity was at a maximum before $\mathrm{AD} 1650$ and between $\mathrm{AD} 1730$ and 1830. During these two periods avalanches had sufficient basal magnitude to reach the zone of the deposits. At low elevation since AD 1650 the magnitude and frequency of avalanches has declined.

The relatively good correspondence between avalanche boulder tongue and glacier behaviour in the Massif des Ecrins to climatic variation which occurred since the Little Ice Age confirms that avalanche boulder tongues can be viewed as reliable indicators of the activity of certain slope processes within the periglacial zone.

\section{ACKNOWLEDGEMENTS}

This study has been conducted as part of the APN 'Impacts des fluctuations climatiques enregistrées depuis le Petit Age Glaciaire sur les versants soumis aux processus périglaciaires et aux mutations du pastoralisme dans le Massif des Ecrins', and of the Eclipse programmes which were supported by the CNRS. Special thanks are due to L. Blikra and D. McCarroll for critically reading the manuscript.

\section{REFERENCES}

André MF. 1995. Holocene climate fluctuations and geomorphic impact of extreme events in Svalbard. Geografiska Annaler 77A: 241-250. André MF. 1997. Holocene rockfall retreat in Svalbard: a triple-rate evolution. Earth Surface Processes and Landforms 22: 423-440.

Benedict JB. 1990. Lichen mortality due to late-lying snow: results of a transplant study. Arctic and Alpine Research 22: 81-99.

Benedict JB. 1991. Experiments on lichen growth II. Effects of a seasonal snow cover. Arctic and Alpine Research 23: 189-199.

Blikra LH, Nemec W. 1993. Postglacial avalanche activity in western Norway: Depositional facies sequences, chronostratigraphy and palaeoclimatic implications. In Solifluction and Climatic Variation in the Holocene, Frenzel B (ed.). European Science Foundation.

Blikra LH, Nemec W. 1998. Postglacial colluvium in western Norway: depositional processes, facies and paleoclimatic record. Sedimentology 45: 909-959.

Blikra LH, Selvik SF. 1998. Climatic signals recorded in snow avalanche-dominated colluvium in western Norway: depositional facies successions and pollen record. The Holocene 8: 631-658.

Bocquet G. 2001. Quelques indications sur les caractéristiques météorologiques dans le vallon du plan de l'Alpe (Haute Romanche) au cours de ces dernières années (Massif des Ecrins, France). Revue de Géographie Alpine 3: 81-89. 
Bull WB, Schlyter P, Brogaard S. 1995. Lichenometric analysis of the Kärkerieppe slush-avalanche fan, Kärkevagge, Sweden. Geografiska Annaler 77A: 231-240.

Evin M. 1987. Dynamique, répartition et âge des glaciers rocheux des Alpes du Sud. Thèse d'Etat, Institut de Géographie Alpine, Université de Grenoble.

Evin M, de Beaulieu JL. 1985. Nouvelles données sur l'Age de la mise en place et les phases d'activité du glacier rocheux de Marinet 1 (Haute-Ubaye, Alpes du Sud Françaises). Méditerranée 4: 21-30.

Eybergen FA, Inmeson AC. 1989. Geomorphological processes and climate change. Catena 16: 307-319.

Föhn PMB. 1992. Climate change, snow cover and avalanches. Catena Supplement 22: 11-21.

Francou B. 1983. Géodynamique des dépôts de pied de paroi dans l'étage périglaciaire. Revue de Géologie Dynamique et de Géographie Physique 5: 411-424.

Francou B. 1988. L'éboulisation en haute montagne. Thèse de Doctorat d'état, Centre de géomorphologie du CNRS, Éditec, Caen.

Francou B, Reynaud L. 1992. 10-years superficial velocities on a rock glacier. Laurichard, French Alps. Permafrost and Periglacial Processes 3: 209-213.

Francou B, Fabre D, Pouyaud B, Jomelli V, Arnaud Y. 1999. Symptoms of degradation in a tropical rock glacier (Andes of Bolivia, $21^{\circ}$ S). Permafrost and Periglacial Processes 10: 91-100.

Gautier E. 1992. Recherches sur la morphologie et la dynamique fluviale dans le bassin du Buech (Alpes du Sud). Thèse Doct. Geo., Paris X.

Gray JT. 1973. Geomorphic effects of avalanches and rockfall on steep mountains slopes in the central Yukon Territory. In Research in Polar and Alpine Geomorphology, Proceedings of the 3rd Guelph Symposium on Geomorphology, Fahey BD, Thompson RD (eds). GeoAbstracts: Norwich; 107-117.

Grove JM. 1972. The incidence of landslides, avalanches and floods in western Norway during the Little Ice Age. Arctic and Alpine Research 4: 131-138.

Grove JM. 1988. The Little Ice Age. Routledge: London.

Grove JM, Battagel A. 1983. Tax records from western Norway, as an index of Little Ice Age environmental and economic deterioration. Climatic Change 5: 265-282.

Haeberli W. 1985. Creep and Mountain Permafrost: Internal structure and flow of alpine rock glaciers. Mitteilungen der Versuchsanstalt für Wasserbau, Hydrologie und Glaciologie 77: ETH Zurich.

Haeberli W, Beniston M. 1998. Climate change and its impacts on glaciers and permafrost in the Alps. Ambio 27: 258-265.

Hamilton S, Whalley WB. 1995. Preliminary results from the lichenometric study of the Nautardalur rock glacier, Tröllaskagi, Nothern Iceland. Geomorphology 12: 123-132.

Hétu B. 1990. Evolution récente d'un talus d'éboulis en milieu forestier, Gaspésie, Quebec. Géographie physique et Quaternaire 44: 199_ 215.

Humlum O. 1996. Origin of rock glaciers: observations from Mellemfjors, Disko Island, Central west Greenland. Permafrost and Perglacial Processes 7: 361-380.

Humlum O. 1999. Late-Holocene climate in central west Greenland: meteorological data and rock glacier isotope evidence. The Holocene 9: $581-594$.

Innes JL. 1985a. Lichenometry. Progress in Physical Geography 9: 187-254.

Innes JL. 1985b. Magnitude-frequency relations of debris flows in northwest Europe. Geografiska Annaler 67A: 23-32.

Innes JL. 1986a. The use of percentage cover measurements in lichenometric dating. Arctic and Alpine Research 18: 209-216.

Innes JL. 1986b. Influence of sampling design on lichen size-frequency distributions and its effects on derived lichenometric indices. Arctic and Alpine Research 18: 201-208.

Jacobeit J, Jönsson P, Bärring L, Beck C, Ekström M. 2001. Zonal indices for Europe 1780-1995 and running correlation temperature. Climatic Change 48: 219-241.

Jomelli V. 1997. Géodynamique des dépôts d'avalanches: analyses morphométriques et sédimentologiques. Thèse Doct. Géogr. Université Denis Diderot de Paris 7.

Jomelli V. 1999. Dépôts d'avalanches dans les Alpes françaises: géométrie, sédimentologie et géodynamique depuis le Petit Age Glaciaire. Géographie physique et Quaternaire 53: 199-209.

Jomelli V, Bertran P. 2001. Wet snow avalanche deposits in the French Alps: structure and sedimentology. Geografiska Annaler 83A: 1528.

Jomelli V, Francou B. 2000. Comparing characteristics of rockfall talus and snow avalanche landforms in an alpine environment using a new methodological approach. Geomorphology 35: 181-192.

Kotarba A, Stromquist L. 1984. Transport sorting and deposition processes of alpine debris slope deposits in the Polish Tatra mountains. Geografiska Annaler 66A: 285-294.

Kotarba A, Kaszowski L, Krzemien K. 1987. High-mountain denudation system of the Polish Tatra mountains. Geographical Studies Special Issue, No. 3. The Publishing House of the Polish Academy of Sciences: Wroclaw.

Lafortune M, Filion L, Hétu B. 1997. Dynamique d'un front forestier sur un talus d'éboulis actif en climat tempéré froid (Gaspésie, Quebec). Géographie physique et Quaternaire 51: 67-80.

Le Roy Ladurie E. 1983. Histoire du climat depuis l'an mil. Flammarion: Paris.

Luckman BH. 1988. Debris accumulation patterns on talus slopes in Surprise Valley, Alberta. Géographie physique et Quaternaire 42: 247278.

Luckman BH, Fisk CJ. 1995. Estimating long term rockfall accretion rates by lichenometry. Steepland Geomorphology 221-254.

Mathews JA, McCarroll D. 1994. Snow avalanche impact landforms in Breheimen, southern Norway. Origin, Age and Paleoclimatic implications. Arctic and Alpine Research 26: 103-115.

McCarroll D. 1993. Modelling late-Holocene snow-avalanche activity; incorporating a new approach to lichenometry. Earth Surface Processes and Landforms 18: 527-539.

McCarroll D. 1994. A new approach to lichenometry: dating single-age and diachronous surfaces. The Holocene 4: 383-396.

McCarroll D, Matthews JA, Shakesby RA. 1995. Late Holocene snow-avalanche activity in Southern Norway: interpreting lichen sizefrequency distributions using an alternative to simulation modelling. Earth Surface Processes and Landforms 20: 465-471. 
McCarroll D, Shakesby RA, Matthews JA. 1998. Spatial and temporal patterns of late Holocene rockfall activity on a Norwegian talus slope: a lichenometric and simulation-modeling approach. Arctic and Alpine Research 30: 51-60.

Norem H, Irgens F, Schieldrop B. 1989. Simulation of snow avalanche flow in the run-out zone. Annals of Glaciology 13: $218-225$.

Nyberg R. 1985. Debris flows and slush avalanches in northern Swedish Lappland. Medd. Lunds Univ. Geogr. Inst. Avh., 97.

Nyberg R, Lindh L. 1990. Geomorphic features as indicators of climatic fluctuations in a periglacial environment, Northern Sweden. Geografiska Annaler 72A: 203-210.

Pech P, Jomelli V, Baumgart-Kotarba M, Bravard J-P, Chardon M, Jacob N, Kedzia S, Kotarba A, Raczkowska Z, Tsao C. 2003. A lichenometric growth curve in the French Alps: Ailefroide and Veneon valleys; Massifs des Ecrins. Geodinamica Acta. (in press).

Porter SC, Orombelli G. 1980. Catastrophic rockfall of September, 12, 1717 on the Italian flank of the Mont Blanc massif. Zeitschrift für Geomorphologie 24: 200-218.

Rapp A, Nyberg R. 1981. Alpine debris flows in northern Scandinavia, morphology and dating by lichenometry. Geografiska Annaler 63A: $183-196$.

10 Rapp A, Nyberg R. 1988. Mass movement, nivation processes and climatic fluctuations in the northern Scandinavian mountains. Norsk Geografisk Tidsskrift 42: 245-253.

Reynaud L. 2001. Histoire des fluctuations des glaciers en remontant le Petit Age de Glace. Colloque SHF variations climatiques et hydrologie, Paris, 43-49.

Schlyster P, Jönsson P, Nyberg R, Persson P, Rapp A, Jonasson C, Rehn J. 1993. Geomorphic process studies related to climate change in Northern Sweden status of current research. Geografiska Annaler 75A: 55-60.

Schneebeli M, Laternser M, Amman W. 1997. Destructive snow avalanches and climate change in the Swiss Alps. Eclogea Geologicae Helvetica 90: 457-461.

Six D, Reynaud L, Letréguilly A. 2001. Bilans de masse des glaciers alpins et scandinaves, leurs relations avec l'oscillation du climat de l'Atlantique nord. CRAS IIa: 693-698.

Van Steijn H. 1996. Debris-flow magnitude-frequency relationships for mountainous regions of Central and Northwest Europe. Geomorphology 15: $259-273$

Vincent C. 2001. Fluctuations des bilans de masse des glaciers des Alpes françaises depuis le début du 20em siècle au regard des variations climatiques. Colloque SHF variations climatiques et hydrologie, Paris, 49-56.

Vincent C. 2002. Influence of climate change over the 20th century on four French glacier mass balances. Journal of Geophysical Research (in press).

Vincent C, Vallon M. 1997. Meteorological controls on glacier mass-balance: empirical relations suggested by Sarennes glaciers measurements (France). Journal of Glaciology 43: 131-137.

Voellmy A. 1955. Über die Zerstörungskraft von Lawinen. Schweizerische Bauzeitung Jahrg: 159-162. 
From: Production Department

John Wiley \& Sons Ltd

The Atrium, Southern Gate

Chichester

West Sussex

P019 8S0

\section{Queries Form Publisher}

Title of Journal: Earth Surface Processes and Landforms

\section{Paper Ref. No.: ESP1050}

During the copyediting of your article the following queries have arisen. Please mark your corrections and answers to these queries directly on to the proof at the relevant place - do not mark your corrections on this query sheet.

Many thanks for your assistance.

\begin{tabular}{|l|l|l|}
\hline Query Refs. & Query & Remarks \\
\hline $\mathbf{1}$ (On p. 3) & This is 2003 (in press) in ref. list. please check date & \\
\hline $\mathbf{2}$ (On p. 5) & $\begin{array}{l}\text { Do circled values represent fractions, (e.g. } \\
\text { seven-tenths)? Would they be better expressed as } \\
\text { percentages (e.g. } 9 / 10=\text { lowermost } 10 \% \text { of the profile)? }\end{array}$ & \\
\hline $\mathbf{3 ~ ( O n ~ p . ~ 1 1 ) ~}$ & Volume no.? & \\
\hline $\mathbf{4}$ (On p. 12) & in full? & \\
\hline $\mathbf{5}$ (On p. 12) & published yet? & \\
\hline $\mathbf{6 ~ ( O n ~ p . ~ 1 2 ) ~}$ & published yet? & \\
\hline
\end{tabular}

